\title{
The use of dinoprostone at third trimester in pregnant women with oligohydramnios
}

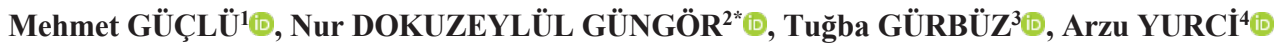 \\ ${ }^{1}$ Department of Obstetrics and Gynecology, Marmara University Pendik Education and Research Hospital, Istanbul, Turkey \\ ${ }^{2}$ Department of Obstetrics and Gynecology, Medical Park Göztepe Hospital, Istanbul, Turkey \\ ${ }^{3}$ Department of Obstetrics and Gynecology, Medistate Hospital, Istanbul, Turkey \\ ${ }^{4}$ Memorial Hospital, IVF, Kayseri, Turkey
}

\begin{abstract}
\begin{tabular}{ccccc}
\hline Received: 23.02 .2021 & $\bullet$ & Accepted/Published Online: 01.03 .2021 & $\bullet$ & Final Version: 30.08 .2021 \\
\hline
\end{tabular}
Abstract

The aim of this study was comparing the efficacy of dinoprostone administration for labour induction in pregnant women with oligohydramnios and in pregnant women with normal amniotic fluid volume at third trimester. This retrospective study included 187 pregnant women between January 2015-December 2020. Four quadrant technique was used to determine amniotic fluid index. The cases in the study were divided into two groups as Group:1(the ones with oligohydramnios) and Group:2 (the ones with normal amniotic volume) Age ,gravida, parity ,gestational week according to the last date of menstruation, Bishop score, dilatation ,hours elapsed after the first contraction, hours elapsed after active contraction, labour entry time (hour), time elapsed until delivery (hour), birth weight, Apgar score 0th minute and 5th minute and their distribution between the groups showed similarity ( $p>0.05)$. The values of amniotic fluid index (AFI) $(p<0.001)$ and effacement $(p=0.012)$ were found to be significantly higher in Group 2 compared to the values of the cases in the Group $1(\mathrm{p}<0.05)$. It was found in the analysis that the findings of premature rupture of membrane (PROM), oxytocin augmentation need, tachysystole, vaginal delivery rate, caesarean delivery rate, meconium stained amnion rate, neonatal intensive care unit (NICU) need, postpartum hemorrhage, and transfusion need $(p=0.394)$ were similar between two groups $(\mathrm{p}>0.05)$. We can state that dinoprostone can be used safely and effectively to induce labor in third trimester pregnancies both with normal AFI and oligohydramnios.
\end{abstract}

Keywords: dinoprostone, induced labour, oligohydramnios

\section{Introduction}

Oligohydramnios is associated with increased morbidity and mortality. It is defined as five centimeters or less of amniotic fluid index that is measured by ultrasound (1). Almost $12 \%$ of pregnancies are complicated with oligohydramnios leading to fetal heart rate abnormalities and fetal hypoxemia due to cord compression during labor (2). The prevalence of oligohydramnios in early pregnancies is less than $1 \%$ (3). Maximal vertical pocket (MVP) and amniotic fluid index (AFI) are two important methods to diagnose oligohydramnios. The effects of oligohydramnios on neonatal outcomes are unclear; whereas some authors did not show any adverse effects, others have shown higher rates of neonatal intensive care unit (NICU) admissions, lower Apgar scores and higher rate of meconium aspiration syndrome (MAS). It is mostly an isolated finding, and it is recommended by the American College of Obstetricians and Gynecologists (ACOG) that delivery should be initiated between $360 / 7$ and 37 6/7 weeks in pregnancies that is complicated by oligohydramnios in order to prevent antepartum stillbirth (4). Dinoprostone is the first option that is recommended for the induction of labour induction (IOL) in late-term pregnancy (LTPs) (5). It is a synthetic preparation which is chemically identical to prostaglandin $\mathrm{E}_{2}\left(\mathrm{PGE}_{2}\right)$ that is delivered with a cervical gel or vaginal insert, and which provides sufficient $\mathrm{PGE}_{2}$ to local tissues to induce cervical ripening (6). Prostaglandin analogues are commonly administered to pregnant women in clinical practice to prepare the immature cervix for delivery (7).The sustained-release vaginal ovule form containing $10 \mathrm{mg}$ of dinoprostone of these analogues is available in Turkey (PROPESS OVULES Ferring) and it has been approved by the Ministry of Health to be used in the induction of labour beginning from 37 weeks (8). In this retrospective study, we aimed to assess the possible effects of labor induction with Dinoprostone at third trimester pregnancies with or without oligohydramnios.

\section{Materials and methods}

This retrospective study included 187 pregnant women at third trimester, and it was conducted between January 2015December 2020. Four quadrant technique was used to determine amniotic fluid index. Deepest, vertical length of each pocket of fluid is measured in each quadrant and summed 
up. Term pregnancy is diagnosed if at least 37 gestational weeks are completed according to date of last menstruation or first trimester ultrasound. Patients having single fetus in vertex presentation with estimated fetal birth weight $<4000 \mathrm{~g}$ with normal non-stress test (NST) were included. Exclusion criteria were presence of twin pregnancy, spontaneous labor, any maternal condition complicating pregnancy (e.g., hypertension, Diabetes Mellitus, other systemic diseases), contraindications of labor induction e.g., cephalopelvic disproportion (CPD), history of uterine surgery, placental anomalies. After pelvic and ultrasonographic examination were completed, Dinoprostone (Propess $10 \mathrm{mg}$, Ferring AB, Limhamn, Sweden) was placed to posterior fornix. NST and pelvic examinations were repeated in 2-3 h intervals. Oxytocin augmentation was introduced in case of hypotonic uterine dysfunction, at least $6 \mathrm{~h}$ after removal of the ovule. Patients in active phase of labor were followed properly. In lack of active uterine contractions, ovule was removed $12 \mathrm{~h}$ after the application and the second ovule was introduced $24 \mathrm{~h}$ after the first administration. Lack of active uterine contractions and progressive cervical changes within $24 \mathrm{~h}$ following the second application was accepted as induction failure and Cesarean sections were performed. The statistical data analysis was conducted through Statistical Package for the Social Sciences (SPSS) 23.0 package program. The categorical measurements were summarized as numbers and percentages. Continuous measurements, on the other hand, were summarized as mean and standard deviation (median and minimum-maximum when needed). Chi-square test and Fischer's Precision Test were used in comparison of categorical variables. The variables' conformity to normal distribution was investigated by using

Table 1. Demographic characteristics of both groups

\begin{tabular}{|c|c|c|c|c|}
\hline & $\begin{array}{c}\text { Oligohydramnios } \\
(n=59)\end{array}$ & $\begin{array}{l}\text { Normal } \\
(\mathrm{n}=128)\end{array}$ & $\begin{array}{l}\text { All Patients } \\
(\mathbf{n}=187)\end{array}$ & \multirow[t]{2}{*}{$\mathbf{p}$} \\
\hline & Mdn (Min-Max) & Mdn (Min-Max) & Mdn (Min-Max) & \\
\hline Age(y) & $25(17-47)$ & $25(17-42)$ & $25(17-47)$ & 0.696 \\
\hline Gravida & $1(1-6)$ & $1(1-11)$ & $1(1-11)$ & 0.411 \\
\hline Parity & $0(0-3)$ & $0(0-4)$ & $0(0-4)$ & 0.211 \\
\hline $\begin{array}{l}\text { Gestational week according to the last } \\
\text { date of menstruation }(\mathrm{w})\end{array}$ & $39(31-42)$ & $39(34-43)$ & $39(31-43)$ & 0.466 \\
\hline Amniotic fluid index (AFI)(mm) & $40(10-50)$ & $80(60-180)$ & $70(10-180)$ & $<0.001$ \\
\hline Bishop & $1(0-3)$ & $1(0-3)$ & $1(0-3)$ & 0.326 \\
\hline Dilatation(cm) & $1(0-2)$ & $1(0-2)$ & $1(0-2)$ & 0.687 \\
\hline Effacement (\%) & $0(0-60)$ & $0(0-70)$ & $0(0-70)$ & 0.012 \\
\hline $\begin{array}{l}\text { Hours elapsed after the first } \\
\text { contraction(h) }\end{array}$ & $4(1-12)$ & $4(0-18)$ & $4(0-18)$ & 0.508 \\
\hline $\begin{array}{l}\text { Hours elapsed after the active } \\
\text { contraction(h) }\end{array}$ & $6(2-18)$ & $8(0-24)$ & $8(0-24)$ & 0.286 \\
\hline Labour entry time (hour) & $10(3-25)$ & $12(3-30)$ & $11(3-30)$ & 0.133 \\
\hline Time elapsed until delivery (h) & $14(4-48)$ & $18(4-55)$ & $17(4-55)$ & 0.284 \\
\hline New-born weight(g) & $3080(1685-3970)$ & $3195(1820-4680)$ & $3170(1685-4680)$ & 0.080 \\
\hline Newborn Apgar scores $0^{\text {th }}$ minute & $9(4-9)$ & $9(2-10)$ & $9(2-10)$ & 0.586 \\
\hline Newborn Apgar scores $5^{\text {th }}$ minute & $10(7-10)$ & $10(5-10)$ & $10(5-10)$ & 0.678 \\
\hline
\end{tabular}

Mdn:median, min:minimum, max:maximum, Amniotic fluid index (AFI) visual (histogram and probability graphs) and analytical methods (Kolmogorov-Smirnov/Shapiro-Wilk Tests). In comparison of continuous measurements between the groups Mann Whitney U tests were used for parameters which were not showing normal distribution. Statistical significance level was taken as 0.05 in all tests.

\section{Results}

The cases in the study were divided into two groups as Group:1(the ones with oligohydramnios) and Group:2 (the ones with normal amniotic volume). Age $(p=0.696)$, gravida $(p=0.411)$, parity $(p=0.211)$, gestational week according to the last date of menstruation $(\mathrm{p}=0.466)$, Bishop score $(\mathrm{p}=$ $0.326)$, dilatation $(p=0.687)$, hours elapsed after the first contraction $(\mathrm{p}=0.508)$, hours elapsed after active contraction $(p=0.286)$, labour entry time (hour) $(p=0.133)$, time elapsed until delivery (hour) $(\mathrm{p}=0.284)$, new-born weight $(\mathrm{p}=0.080)$, new-born Apgar score $0^{\text {th }}$ minute $(\mathrm{p}=0.586)$ and $5^{\text {th }}$ minute $(\mathrm{p}$ $=0.678)$ and their distribution between the groups showed similarity $(p>0.05)$. The values of AFI $(p<0.001)$ and effacement $(p=0.012)$ were found to be significantly higher in Group 2 compared to the values of the cases in the Group 1 ( $p$ $<0.05$ ) (Table 1).

In Table 2, it was found in the analysis that the findings of premature rupture of membrane $(\mathrm{PROM})(\mathrm{p}=0.119)$, oxytocin augmentation need $(\mathrm{p}=0.564)$, tachysystole $(\mathrm{p}=0.408)$, vaginal delivery rate $(\mathrm{p}=0.434)$, caesarean delivery rate $(\mathrm{p}=$ $0.498)$, MAS rate $(p=0.530)$, NICU need $(p=0.753)$, postpartum hemorrhage $(\mathrm{p}=0.533)$, and transfusion need $(\mathrm{p}=$ $0.394)$ (Table 2 ) were similar between two groups ( $\mathrm{p}>0.05)$. 
Table 2. Clinical results of both groups

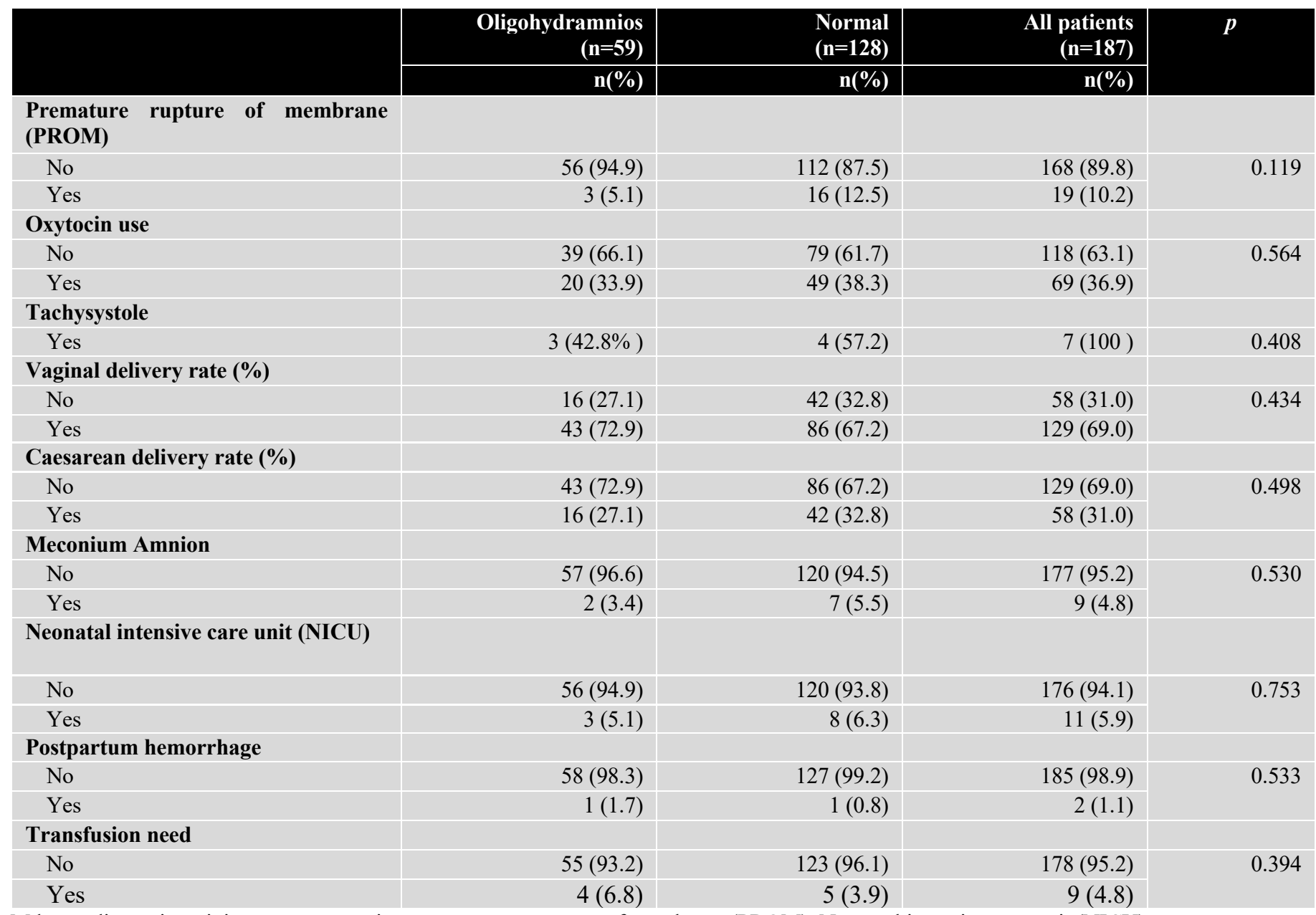

Mdn: median, min: minimum, max: maximum, premature rupture of membrane (PROM), Neonatal intensive care unit (NICU)

\section{Discussion}

In this study the clinical results of dinoprostone use for labour induction between two groups were similar. Oligohydramnios is a relatively common complication of pregnancy, and it is frequently experienced in clinical practice (9). It refers to the volume of amniotic fluid that is less than expected according to the age of pregnancy. It is typically diagnosed by ultrasound and it can be defined as qualitative (e.g. normal, decreased) or quantitative (e.g. $[\mathrm{AFI}]<5)(10)$. Like our results, in the study conducted by Çıkrı et al., it was demonstrated that labor induction with dinoprostone complicated with oligohydramnios was as safe and effective as it was in pregnancies with normal AFI (11). Approximately half of all PGE, ripening studies in term women's have indicated a significant decline in the cesarean delivery rate (12). In Carlan et al study $10(45 \%)$ and $15(68 \%)$ of the study and control group patients respectively had required a cesarean delivery $(\mathrm{P}=0.22)$. In our study, cesarian delivery rate was $27 \%$ in Group 1 and $32.8 \%$ in Group 2 respectively and it was lower than previous studies (13). Cervical ripening is an active biochemical process, similar to an apyretic inflammatory reaction controlled by multiple factors: progesterone, PGs, nitrous oxide (NO), and inflammatory cytokines, such as IL-1, IL-8, and TNF- $\alpha(14,15)$. A study confirm that PGE analogs stimulate cervical NO release in pregnancy (16). Thus, dinoprostone could possibly activate a chain reaction in the cervix of pregnant women, as the initial NO stimulation caused by the $\mathrm{PGE}_{2}$ analog is followed by a local secretion of PGs triggered by NO. Both responses account for cervical ripening in the pregnant patients (17). Prostaglandins have been reported to cause more tachysystole compared with mechanical methods (18). In another study, the rate of tachysystole was found to be significantly higher in cases which had caesarean delivery compared to cases which had vaginal delivery after dinoprostone administration (19). In our study, no significant difference was found between the groups in terms of the status of tachysystole. A study presented that there was no significant difference in terms of birth weight and APGAR scores between women who gave vaginal delivery after induction with dinoprostone and women who had caesarean section (19). Our study similarly revealed that there was no significant difference between the groups in terms of birth weight and APGAR scores. A study found lower birth weights in pregnancies complicated by oligohydramnios (20). But in our study the birth weights were similar between two groups. However, although there were no major maternal or fetal complications in our study, the retrospective study design precludes us from ruling out minor maternal or fetal complications or later neonatal complications. 
We can state that dinoprostone can be used safely and effectively to induce labor in third trimester pregnancies both with normal AFI and oligohydramnios.

\section{Conflict of interest}

None to declare.

\section{Acknowledgments}

None to declare.

\section{References}

1. Phelan J, Smith CV, Broussard P, Small M. Amniotic fluid volume assesment using the four-quadrant technique in the pregnancy between 36 and 42 weeks. J Reprod Med. 1987; 32(7): 540-542.

2. Rath W. Clinical evaluation of controlled-release dinoprostone for cervical ripening - a review of current evidence in hospital and outpatient settings. J Perinat Med. 2005; 33(6),491-499.

3. Hou L, Wang X, Hellerstein S, Zou L, Ruan Y, Zhang W. Delivery mode and perinatal outcomes after diagnosis of oligohydramnios at term in China.J Matern Fetal Neonatal Med. 2020; 33(14), 2408-2414.

4. ACOG. Medically indicated late-preterm and early-term deliveries. Committee Opinion No. 560. Obstet Gynecol. 2013; 121(4),908-910

5. Wei Y, Li X, Zhang Y, Guo Y, Yin B, Chen D, et al. Comparison of Dinoprostone and Oxytocin for the Induction of Labor in LateTerm Pregnancy and the Rate of Cesarean Section: A Retrospective Study in Ten Centers in South China. Med Sci Monit. 2019; 25:8554-8561.

6. Bierut A, DowgiałłoSmolarczyk J, Pieniążek I, Pacocha Stelmachowski J, Pacocha K, Sobkowski M. et al. Multicenter Study. Misoprostol Vaginal Insert in Labor Induction: Adv Ther. 2016; .33(10),1755-1770.

7. Yörük Ö, Öksüzoğlu A, Engin-Üstün Y, Aktulay A, Yapar Eyi E, Erkaya S. Bishop skoru 4 ve altında olan gebelerde doğum indüksiyonunda dinoproston ve oksitosin kullanılmasinın karşılaştırılması. Perinatoloji Dergisi. 2013; 21(3),107-112.

8. Çetinkaya ȘE, Söylemez F. Doğum indüksiyonunda bașarıyı etkileyen faktörler ve doğum indüksiyonu yöntemleri.Ankara Üniv Tip Fak Mecm. 2013; 66(1): 25-32.

9. Brace RA. Physiology of amniotic fluid volume regulation. Clin Obstet Gynecol. 1997; 40(2): 280-289.

10. Hedriana, HL. Ultrasound measurement of fetal urine flow. Clin obstet gynecol. 1997; 40(2): 337-351.

11. Akdag Cirık D, Taskın EA, Karcaaltıncaba D, Dai OJ. Study of uterine and fetal hemodynamics in response to labor induction with dinoprostone in prolonged pregnancies with normal amniotic fluid and oligohydramnios. J Matern Fetal Neonatal Med. 2014; 27(7): 691-695.

12. Raybum WF. Prostaglandin E gel for cervical ripening and induction of labor: A critical analysis. Am J Obstet Gynecol. 1989; 160(3): 529-534.

13. Carlan SJ, O'Brien WF, Logan S. Serial Intravaginal Prostaglandin E2 Gel Cervical Ripening in Preterm Pregnancies. Prostaglandins. 1996; 52(3),237-246.

14. Chwalisz K, Benson M, Scholz P, Daumj Beier IHM, Legelhartulg C. Cervical ripening with the cytokine's interleukin-8, interleukin$1 \beta$ and tumor necrosis factor- $\alpha$ in guinea-pigs. Hum Reprod. 1994; 9(11),2173-2181.

15. Kelly RW, Illingworth $P$, Baldie G, Laesk R, Brower S, Calder AA. Progesterone control of interleukin- 8 production in endometrium and chorio-decidual cells underlines the role of neutrophils in menstruation and parturition. Hum Reprod. 1993; 9(2),253-258.

16. Vaisanen-Tommiska M, Mikkola TS. Ylikorkala O. Misoprostol induces cervical nitric oxide release in pregnant, but not in nonpregnant women. Am J Obstet Gynecol. 2005; 193(3),790 796.

17. Chiossi G, Verocchi G, Venturini P, Facchinetti F. Changes in Cervical Nitric Oxide Concentration Correlate with Bishop Score and Cervical Length Modifications in Prostaglandin E2-Mediated Induction of Labor. J Soc Gynecol Investig. 2006; 13(3), 203-208.

18. Hofmeyr GJ. Induction of labour with an unfavourable cervix.Best Pract Res Clin Obstet Gynaecol. 2003; 17(5),777-794.

19. Budak MŞ, Cihan K, Akgöl S, Şentürk MB, Kanat Pektaş M, Görük NY, et al. Prostaglandin E2 ile doğum indüksiyonu: Kadın Doğum ve Çocuk Hastalıkları Hastanesi Deneyimi. JinekolojiObstetrik ve Neonatoloji Tıp Dergisi. 2016; 13(2),61-64.

20. Locatelli A, Vergani P, Toso L, Verderio M, Pezzullo JC, Ghidini A. Perinatal outcome associated with oligohydramnios in uncomplicated term pregnancies. Arch Gynecol Obstet 2004; 269(2), 130-133. 